\title{
THE DEAD HAND OF THE FOUNDERS? ORIGINAL INTENT AND THE CONSTITUTIONAL PROTECTION OF RIGHTS AND FREEDOMS IN AUSTRALIA
}

\author{
Haig Patapan ${ }^{1}$
}

FEDERATION AND RIGHTS

An innovation in constitutionalism

Andrew Inglis Clark and the American connection

Orthodox constitutionalism

$\underline{\text { RIGHTS AND THE CONVENTION DEBATES }}$

$\underline{\text { Just terms }}$

Trial by jury

Freedom of religion

Privileges and immunities, due process, and equal protection

Convention debates and the founders' intention

$\underline{\text { ORIGINALISM AND THE "DEAD HAND" OF THE FOUNDERS }}$

$\underline{\text { CONCLUSION }}$

$\underline{\text { FOOTNOTES }}$

The Australian High Court has in general rejected the use of extrinsic historical material in the interpretation of the Constitution. ${ }^{2}$ Though it has consistently claimed that in interpreting a Constitutional provision it is giving effect to the intentions of the founders, it has not been prepared to turn to the convention debates, draft constitutional bills or other primary records in order to ascertain the founders' intentions. The intention is to be ascertained from the ordinary and natural meaning of the words themselves, relying on the proper legal methods of construction and interpretation. ${ }^{3}$ However, even when this rule was considered to be settled doctrine there were exceptions. In those cases where the words were ambiguous the Court could turn to the drafts of the Constitution "as a matter of history of 
legislation". ${ }^{4}$ As well, convention debates could be referred to "for the purpose of seeing what was the subject matter of discussion, what was the evil to be remedied, and so forth"..

However, in its more recent decisions the Court has suggested that it may be prepared to give greater recognition to such historical material. ${ }^{-}$In Cole $v$ Whitfield the majority suggested that convention debates could be consulted "for the purpose of identifying the contemporary meaning of language used, the subject to which that language was directed and the nature and objectives of the movement towards federation from which the compact of the Constitution finally emerged". ${ }^{.}$And in New South Wales $v$ Commonwealth (the Corporations case) ${ }^{8}$ the Court relied on the convention debates in order to interpret the Commonwealth's corporations power. This new perspective is still constrained, however, by the requirement that, at least in the first instance, the words construed be ambiguous. Nevertheless, such a step has been described by some commentators as an advance on the Court's traditional literalism and legalism since the notion of ambiguity is a difficult concept to contain..

It is arguable that the Court's recent implied rights decisions have effectively removed this initial constraint of "ambiguity" so that there is now no real limit to the use of historical materials in giving meaning to the terms of the Constitution. ${ }^{10}$ This proposition can be defended on the basis that the Court's implied rights decisions, though relying on specific provisions in the Constitution, have used them as merely starting points for constructing a meaning that exists, if at all, within the interstices of the provisions. In other words, the Court's recognition of implied rights means that it is articulating the general intent or animating spirit of the enactment as a whole. Precisely because the rights are implied, there is no requirement for the presence of textual ambiguity; there is nothing to constrain the Court from looking at the founders' intentions in attempting to understand the nature of the Constitution as a whole. Consequently, since implied rights draw upon the liberal foundations of the Constitution, the Court will in time need to elucidate its understanding of the founders' notions of citizenship, rights and freedoms.

What then are the founders' conceptions of liberalism and Australian constitutionalism? A comprehensive answer to this profound question is clearly beyond the scope of this paper. Nevertheless, it is possible to look to Australia's founding in order to gain some insight into the philosophical presuppositions of the founders and the extent to which these ideas contributed to the shaping of the Australian Constitution. A useful starting point in this endeavour is an attempt to discern the founders' notions of rights. ${ }^{11}$ Such an understanding allows a clearer access to the notion of liberalism and progress presupposed by the founders and thereby the nature, extent and form of freedom guaranteed by the Constitution. Accordingly, we will explore this question by turning to what the founders themselves actually said about rights in the convention debates. On what basis did the founders include specific rights in the Constitution? What was their understanding of these rights? What sorts of rights were excluded and for what reasons? These are some of the questions that will be addressed in the context of the convention debates and the drafting of the Constitution. 
The first part of the paper locates the specific rights that were proposed to be entrenched into the Constitution in the context of the prevailing Australian constitutionalism and the innovation that was federalism. The second part turns to the federation debates and the founders' discussions of the rights provisions to ascertain their understanding of these rights and of the notions of progress, freedom and liberalism implicit in such understanding. In its concluding part the paper will consider the extent to which the founders' notion of liberalism would favour the Court's principles of constitutional interpretation and implied rights.

\section{FEDERATION AND RIGHTS}

\section{An innovation in constitutionalism}

It is remarkable the extent to which the Australian Constitution was "home grown" and secured by popular mandate. $\frac{12}{}$ Federation appeared to solve a number of the problems faced by the Colonies. $\underline{\underline{13}}$ However, it represented a major change in direction in Australian constitutional heritage, a departure from the prevailing British constitutionalism to an American-inspired innovation. Though it was generally accepted that federation was an innovation, the fact that it was not consistent with the prevailing British institutions was perhaps not as immediately perceived by all. The differences came to light in the course of the convention debates when the proposed changes appeared to conflict with, and in some cases undermine, fundamental principles of British government. For example, the major issue that divided the 1891 Convention and seemed to be intractable, jeopardising federation itself, concerned the Senate's powers to amend money bills. ${ }^{14}$ Similarly, it was not clear whether responsible government could co-exist with Federation. ${ }^{15}$ For some, like Sir John Gordon and Dr Cockburn from South Australia, Federation was rigid and written, an artificial entity that would undermine parliamentary sovereignty and thereby limit "that elasticity which had hitherto given birth to our greatest privileges". $\underline{16}$

Despite these differences, Federation appeared to hold out a greater prospect for protecting freedoms: in so far as the Constitution contained express rights provisions, federalism appeared to entrench individual rights and liberties and thereby secure them in a more direct and significant way..$^{17}$ How did the founders view these provisions? To what extent were they meant as a confirmation of existing rights and to what extent were they new protections, consistent with the innovation that was federalism? In order to explore these questions it will be necessary to turn to the drafting of the Constitution and in particular to the contribution of Andrew Inglis Clark.

\section{Andrew Inglis Clark and the American connection}

The Constitution contains few express rights. These include the requirement of acquisition of property on just terms (s 51(xxxi)), the requirement of trial by jury for indictable offences (s 80), freedom of

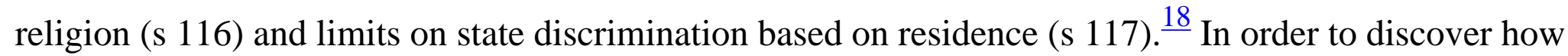
these provisions were incorporated into the Constitution and what they reveal of the founders' 
understanding of rights, it is necessary that we first turn to the contribution of Andrew Inglis Clark.

Until recently, Clark's significant contribution to the drafting of the Constitution was not widely appreciated. ${ }^{19}$ Clark had attended the Australasian Conference in 1890 and, in the Sydney Convention of 1891, served as the Chairman of the Judiciary Committee, as a member of the Constitutional Machinery Committee and its important Drafting Sub-Committee. But, more importantly, he prepared and distributed before the commencement of the Sydney Convention a Draft Bill which formed the basis for the future drafts of the Constitution. $\underline{20}$ The major contribution by Clark can be gauged from Neasey's observation that "of Clark's ninety-six sections, all but eight found their way in the Draft Bill in similar or reworked form, and only ten failed to find a recognisable counterpart in the Constitution". $\underline{21}$

In preparing his Draft Bill, Clark followed the British North America Act in so far as it was appropriate to preserve the existing status of the colonies as dependencies of the British Empire. His main model, however, was the American Constitution:

In all other matters I have followed very closely the Constitution of the United States, with such alterations and additions as the local circumstances of the Colonies and the political history of the United States seemed to indicate to me as being desirable. ${ }^{22}$

This is not surprising because Clark was well versed in American constitutional law as well as its history and literature. From his early days as a member of the American Club in Hobart to his final years as a visitor to that country, he loved and admired American institutions and traditions. $\frac{23}{}$ Deakin described his disposition in these terms:

A persevering student, his sympathies were republican, centering upon Algernon Sydney [sic] among Englishmen, upon Mazzini in Italy, and especially upon the United States, a country to which in spirit he belonged, whose Constitution he reverenced, and whose great men he idolized. $\underline{24}$

It is therefore not surprising to find that Clark's draft followed in general the Constitution of the United States, especially in terms of entrenching a strong judiciary and including individual rights. Accordingly, we find that his draft included a provision requiring jury trials for all crimes (cl 65), a prohibition on the establishment of religion by the federal government, as well as a federal and state guarantee of free exercise of religion (cls 46, 81). ${ }^{25}$ Clark's draft did not contain a privileges and immunities clause nor an equal protection clause. However, Chapter IV, section 17 of the 1891 Sydney draft did include a combination of such clauses. $\frac{26}{}$ This, too, was probably his handiwork because the proposals made in Melbourne in 1898 by the legislature of Tasmania for a more comprehensive hold-all clause were actually those of the Tasmanian Attorney-General, Clark..$^{27}$

These provisions protecting individual rights were included in the Australian Constitution primarily due 
to the work of Clark; and to some extent they were as innovative in form, if not substance, as federalism itself, the more comprehensive innovation borrowed largely from the United States. The extent to which these provisions were foreign to the British, and therefore Australian, political and jurisprudential tradition will come to light when we turn to their discussion in the convention debates. The more immediate question of course is why Clark did not include and adopt all the rights in the United States Constitution, especially the first ten Amendments. One answer is that he selected those rights that were appropriate to the "local circumstances of the Colonies". ${ }^{28}$ More likely, his correspondence and friendship with Oliver Wendell Holmes Jr and his visits to the United States may have, over time, persuaded him of the importance of providing for greater security in the form of constitutional enactments. $\stackrel{29}{~ T h i s ~ m a y ~ e x p l a i n ~ h i s ~ a t t e m p t ~ t o ~ i n c o r p o r a t e ~ a ~ c o m p r e h e n s i v e ~ r i g h t s ~ c l a u s e ~ i n t o ~ t h e ~}$ Constitution in the course of the Melbourne Convention in $1898 . \frac{30}{}$ It is also important to recall that the United States Bill of Rights had not received the expansive reading at the time that it was to have in the course of the twentieth century. Although the Federalist and Anti-Federalist debates had stressed the importance of entrenched guarantees of individual rights, the United States Supreme Court was initially more concerned with securing liberty by maintaining federalism and the separation of powers. $\underline{31}$ Even after the Civil War and the enactment of the Fourteenth Amendment the Court gave a limited reading to these provisions. $\underline{32}$ At the time of the final Australian convention debates, the Supreme Court was prepared to invoke substantive due process to invalidate legislation that limited individual freedom of contract and property. $\frac{33}{3}$ Clark's emphasis on the equivalent of the Fourteenth Amendment may have been due to his appreciation of these developments.

\section{Orthodox constitutionalism}

Clark's attitude may be contrasted with those of the founders who were less well acquainted with American jurisprudence. In the course of the convention debates the founders relied on a number of authors, $\underline{34}$ but the pre-eminent authority was Bryce. Bryce's The American Commonwealth was an obvious source-book on American government and more importantly federalism. $\frac{35}{3}$ According to Deakin, "[a]n authority, to whom we have often referred since 1890, an authority to whom our indebtedness is almost incalculable, is Hon. Mr Bryce". $\frac{36}{\text { In }} 1891$ Parkes had sent to Bryce a copy of the Proceedings and Debates of the 1891 convention. This was followed by an edition of the draft Bill with commentaries commissioned by Parkes to aid public understanding. ${ }^{37}$ In the 1897-98 convention the book lay on the parliamentary table throughout the proceedings. $\underline{38}$

Bryce's work, a reprise on Tocqueville's Democracy in America, provides an account of American government and mores. For our present purposes it is sufficient to discuss his understanding of the major differences between the British and American constitutions. $\frac{39}{}$ To Bryce, the primary distinction was between flexible constitutions such as the British and the rigid, as exemplified by the American. $\stackrel{40}{ }$ Bryce did not emphasise the importance of the American Bill of Rights and the other constitutional amendments. He regarded the first ten amendments to the Constitution as a "supplement or postscript to 
it, rather than changing it". ${ }^{41}$ They secured "the individual citizen and the States against the encroachments of Federal power". As for the Thirteenth and Fourteenth Amendments, he considered these as the "outcome of the War of Sucession, and were needed in order to confirm and secure for the future its results".

With respect to the Bills of Rights in the State Constitutions, Bryce expressed surprise that claims of rights and immunities of individuals against the government "should continue to be repeated in the instruments of today". .43 He ventured two reasons for their inclusion. The first was the "remarkable constitutional conservatism of the Americans". The second was the claim that such provisions constrained arbitrary conduct by legislative majorities that might "be tempted at moments of excitement to suspend the ordinary law and arm the magistrates with excessive powers". 44 Bryce noted that such Bills of Rights were still regarded as "safeguards against tyranny". His response, however, showed him damning with faint praise: "Although such provisions certainly do restrain a legislature in ways which the British Parliament would find inconvenient, few complaints of practical evils thence arising are heard". $\underline{45}$

Underlying Bryce's analysis of Bills of Rights was the more fundamental difference he noted between the American and English perspective regarding the source of threat to freedom. In his Studies in History and Jurisprudence Bryce observed that the American Bill of Rights was meant to protect the citizens against abuse of legislative power.

The English, however, have completely forgotten these old suspicions, which, when they did exist, attached to the Crown and not to the Legislature.

Parliament was for so long a time the protector of Englishmen against an arbitrary Executive that they did not form the habit of taking precautions against abuse of the powers of the Legislature; and their struggles for a fuller freedom took the form of making Parliament a more truly popular and representative body, not that of restricting its authority. $\underline{46}$

However, the overarching theme in his discussion of the American Constitution was that of progress. Although he referred to the guarantees in the Federal and the State Constitutions in his discussion of the tyranny of the majority, the general argument was that there was in fact little of such tyranny in America. Bryce argued that democracy in America had matured and become more sober: "The years which have passed since the war have been years of immensely extended and popularised culture and enlightenment". The breakdown of religious bigotry and the separation of the religious from the political had meant that "the tyranny of the majority is no longer a blemish on the American system". $\stackrel{47}{\text { The }}$ implication was that though constitutional protections existed, they were really no longer necessary. But what happened if some oppression did take place? Bryce appeared to endorse laissez aller rather than judicial intervention: "They argue, not merely that the best way on the whole is to leave a State to itself, but that this is the only way in which a permanent cure of its diseases will be effected". Bad laws will 
make the people themselves suffer and accordingly the "evil will work out its remedy sooner or later". 48

The belief in a progressive civilization undergirded Bryce's general ambivalence towards entrenched rights. Combined with the distinction between "rigid" and "flexible" constitutions it is easy to see why he would have been in favour of the more flexible English model, though he was prepared to accept a federal system for its decided advantages. Yet, even here, in discussing the merits of the federal system and the threat posed by a "despotic central government", he saw the States and not entrenched rights as

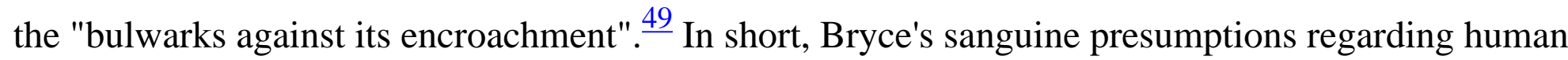
development pre-empted to some extent his concern for securing entrenched rights.

Similar views regarding entrenched rights were entertained by A V Dicey, who also emphasised the importance of the common law and the rule of law in protecting individual liberties. Dicey too was

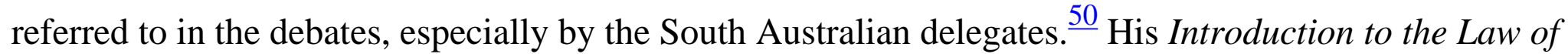
the Constitution published in 1885 was relied upon by the founders to understand and explain the constitutional changes that were being debated. The difference between a flexible and rigid constitution, the notion of parliamentary sovereignty and the rule of law were elaborated at length in the Introduction. As Dicey was Bryce's colleague at Oxford and accompanied him on his American voyage that resulted in The American Commonwealth (the work is dedicated to Dicey and Holland) it is not surprising that there was substantial agreement between the two, especially regarding the constitutional distinctions noted above. Although the idea of human progress and advancement was to some extent presumed in Dicey, he was much more precise in elaborating the reasons for preferring the English remedies as opposed to constitutional definitions or declarations of rights. General declarations, he argued, were often no more than that. Moreover, as general declarations they were often suspended. His claim was that the Rule of Law in England provided a much greater security for the freedom than any written or declared rights. $\underline{51}$

Dicey's rejection of entrenched rights and his theory of parliamentary sovereignty and the rule of law confirmed the prevailing views and in turn were to have a major influence on the founders. He provided the arguments that would justify the retention of the traditional English remedies while being wary of any attempts to entrench rights in the constitution. The claim was that such entrenchment, though laudable, was in practice not adequate to secure liberties.

These opinions and views were largely accepted and repeated in the works of such contemporaries as Quick and Garran, and Harrison Moore. $\frac{52}{}$ For example, Quick and Garran's The Annotated Constitution of the Commonwealth of Australia, the major scholarly commentary on the Constitution written by those who actually took part in the conventions, refers at length to American precedents and jurisprudence but is almost silent on the American Bill of Rights. $\underline{\underline{53}}$ When considering such matters as privileges and immunities and the Fourteenth Amendment, the authors did so in the context of citizenship, stressing that this term was used to express membership in a republican community and therefore was foreign to the British tradition that recognises allegiance to a personal sovereign..$^{54}$ In his Constitution of the 
Commonwealth of Australia, Harrison Moore distinguished between the American Constitution with its Bill of Rights, and the Australian, noting that the American provisions were based on a "spirit of distrust". For Harrison Moore, there were very few guarantees of individual rights in the Australian Constitution because the "great underlying principle is that the rights of individuals are sufficiently secured by ensuring as far as possible to each a share, an equal share, in political power". He put the differences between the two governments in these terms:

The federalism of Australia is the federalism of the United States; her democracy is her own; and the prevalence of the democratic principle is unopposed by anything except the necessity for making a compromise with the principle of State right. $\underline{55}$

Harrison Moore intimated that the distrust shown by the Americans was unwarranted and in essence undemocratic. Although he too was concerned with the rights of the individual he thought they were adequately protected by representative government. In holding these opinions he showed the extent to which there was a remarkable consensus among scholars and politicians regarding the limited merits of entrenching individual rights.

In order to explore in greater detail these opinions and more specifically the founders' views regarding individual rights and the best means for securing them it is necessary to turn to the convention debates themselves where the merits and the claims of these provisions were evaluated and addressed. More specifically, we will consider the debates on each of these express rights to explore the extent to which the founders eschewed treating them as protections for individual freedoms.

\section{RIGHTS AND THE CONVENTION DEBATES}

\section{Just terms}

The Constitution provides that Parliament can only acquire property on just terms from any state or person. ${ }^{56}$ Turning to the Federation debates it is interesting to note that this provision was introduced, not as a measure to limit Parliament's power, but as an attempt to ensure that there was an express provision giving the Commonwealth such a right. The provision was first introduced at the Melbourne Convention by the leader of the Convention, and Australia's first Prime Minister, Barton on the grounds that there "is no express provision in the Constitution for the acquisition by the Commonwealth of any property the acquisition of which might become necessary". $\underline{57}$ Such a grant of power was necessary, according to Quick from Victoria, because "the Commonwealth would be crippled in its future operations if express power were not given in the manner suggested". $\underline{58}$

Turner, the Premier of Victoria, objected to the provision because it had not been discussed before. His initial objection was that it "might enable the Commonwealth to run states into enormous expenditure". In other words this would enable the Commonwealth to be profligate in purchasing property and thereby be a burden on the States. Barton's response was that, by having the requirement to acquire property on 
just terms, the compensation would probably involve arbitration or the verdict of a jury. In the alternative, if

you allowed the acquisition to be carried out by contract, as it would have to be without a clause of this kind, it would be more expensive, and would entail a greater diminution of the surplus returned to the state. $\underline{59}$

Thus Barton defended the requirement for just terms not on the grounds that it would secure the rights of individuals or the state, but on the basis that it made good business sense. Turner responded by objecting to "the use of the words 'just terms' on the ground that they are not proper words to put into the Constitution. We assume that the Federal Parliament will act strictly on the lines of justice". $\underline{\underline{ }}$ The subsection was withdrawn for further consideration. $\underline{61}$

It was subsequently resubmitted in its present form by O'Connor, from New South Wales and a future High Court judge, in the following terms:

Some question has been raised as to whether the Commonwealth has the power inherently of acquiring property under just terms of compensation; that is to say, whether it is not driven to bargain and sale only. It is quite clear that there must be a power of compulsorily taking property for the purposes of the Commonwealth. $\underline{62}$

The discussion above confirms the fact that the founders viewed the section as an express conferral on the Commonwealth of the power of compulsory acquisition of property. The provision was certainly not a measure to ensure that acquisition was to be on just terms. There was no discussion of this aspect of the provision except, as noted above, to show its commercial benefits or to indicate that, for some delegates, just terms were assumed irrespective of their statutory confirmation. Moreover, this discussion concentrated upon the interests of the state and not the individual. In short, the section was essentially a power allocating federal measure and not a civil liberties provision.

\section{Trial by jury}

Clark, relying on the American model, had provided in his original draft that all crimes tried under the authority of the constitution were to be by a jury in the province where the crime was committed. $\underline{63}$ In Griffith's draft of 1891 the clause was altered to refer to the "trial of all indictable offences". .64 This alteration was significant because as Isaacs, the future High Court judge noted, in contrast to the United States clause that referred to "crimes," the Australian provision would not be a limitation on Parliament "because it is within the powers of the Parliament to say what shall be an indictable offence and what shall not". $\underline{65}$

The clause was not discussed in Sydney in 1891. In Adelaide, only Higgins, a liberal from Victoria and 
also a future High Court judge, spoke against it: "All I want is not to tie the hands of the Federal Parliament, but to leave this as a question of expediency for the Federal Parliament to determine". $\underline{66}$

The merits of the provision were discussed at greater length in Melbourne. The Legislative Assembly of South Australia suggested that the section should be amended by omitting the requirement for jury trials. According to Glynn, a Conservative from South Australia who favoured "State's Rights", the "object of the proposal is to render the Federal Parliament as omnipotent within its own authority as the existing Parliaments of the states are at present". He argued that this provision was taken from American precedents that were framed at a time when they feared the loss of one of the "inalienable rights of every British subject in the colonies" and there was no point in copying such a provision "without the existence of the same necessity". In short, "[o]n the ground that you should not fetter the omnipotence of Parliament, I hold that the words should be struck out". $\frac{67}{}$ Higgins supported Glynn's suggested amendment, arguing that no matter how valuable trial by jury was considered to be, "it is not a matter for this Constitution at all". Wise from New South Wales countered both Glynn and Higgins by supporting the clause as a "necessary safeguard to the individual liberty of every subject in every state". He defended the provision by arguing that it did not affect the State's right to legislate with respect to trial by jury; rather it limited the power of the federal Parliament. $\frac{68}{}$ Wise appeared to be more concerned by the fact that the trial may take place away from the citizen's community.

Higgins rejected the claim that trial by jury was a safeguard of liberty as Wise had contended. "If the honourable member were speaking a hundred years ago he might have expected his remark to be applauded when he spoke of trial by jury as being a necessary safeguard of liberty". Higgins did not think that this measure could be regarded any longer as a device to secure civil liberties. He did not deny that it was important to have trial by jury for criminal cases. Rather, his perspective was of someone who saw jury trials as one means among many of deciding litigation:

The issue is whether we are to stereotype this in the Constitution, and to say, no matter what changes may come about in legal procedure and in the mode of dealing with crimes, that we must have a jury, and that nothing but a change in the Constitution can bring about an alteration. $\underline{69}$

The proposed amendment was defeated even though Isaacs, as noted above, suggested that as a means for safeguarding the rights of an accused the section did not fetter Federal Parliament.

The section was given its final form as a result of an amendment proposed by Barton that the words "of all indictable offences" be replaced with "on indictment of any offence." The object of the amendment, according to Barton, was that Parliament should have the power to punish minor offences summarily.

There will be numerous Commonwealth enactments which would prescribe, and properly prescribe, punishment; and summary punishment; and if we do not alter the clause in this way they will have to be tried by jury, which would hamper the administration of justice of minor cases entirely. $\underline{70}$ 
After Isaacs repeated his claim that the section as it stood would have little effect in preserving in all circumstances trial by jury, the amendment was agreed to without objection and appears in the Constitution in its present form.

The evolution of the section in the course of the convention debates is instructive. Clark's original provision modelled on American precedents effectively lost its force when put in terms of trials on indictment. Although the measure was seen by some as a safeguard for liberty, others viewed it as an inappropriate inclusion in a Constitution. In the end any suggestion that the provision was to protect liberty was implicitly abandoned once it was conceded that Federal Parliament should, in the interests of the proper administration of justice, have the power to deny trial by jury in certain minor matters. Thus the spirit of the provision was transformed; no longer wary of Parliament, it now presupposed its good intentions and attempted to facilitate the exercise of its authority.

\section{Freedom of religion}

The discussion in the course of the Conventions of the status of freedom of religion is perhaps the clearest presentation of the difference between the traditional understanding of individual protection and the statutory measures to be included in the Constitution. $\frac{71}{}$ Clark's draft of the section was adopted without discussion until the Melbourne Convention, $\underline{72}$ where Higgins moved an amendment to the section to the effect that neither the States nor the Commonwealth may make a law prohibiting the free exercise of religion, or establishing any religion or religious observance. He was uncomfortable in moving the motion and made clear that he was doing so for a practical reason:

Some people will think that it is idle at this time of day to pass a law to prevent the prohibition of the establishment of religion; but is not idle in the eyes of a number of people whose votes we would like to secure for the Constitution $\underline{\underline{73}}$

The proposed amendment by Higgins attempted to address the concerns of Australian Seventh Day Adventists. The Convention had decided to include in the preamble of the Constitution a reference to the Almighty..$^{74}$ The Australian Seventh Day Adventists feared that such a reference to the Almighty might have subsequently allowed Parliament to enact Sunday observance legislation, prohibiting their practice of working on Sundays and holding Saturday holy. $\frac{75}{}$ Higgins himself was not persuaded of the amendment's intrinsic merit; he saw it as necessary for assuring the passage of the Constitution: "I want to do what is, at the worst, harmless, with a view to secure a greater number of votes in favour of the Constitution". $\underline{76}$

Those who opposed the amendment relied on the anachronistic nature of the measure and the unjustifiable limits it placed on Parliament. Braddon, the Tasmanian Premier, wanted the entire section left out of the amendment or, if retained, to include a provision that allowed the Commonwealth to "prevent the performance of any such religious rites as are of a cruel or demoralising character or 
contrary to the law of the Commonwealth". $\underline{77}$ The South Australians Gordon, Cockburn and Downer agreed with Braddon. Gordon stated that both the States and the Commonwealth should have the right to interfere where "the exercise of religious observances injures the community or any person in the community". Cockburn and Downer claimed that the section was an anachronism. According to Cockburn, the Premier of South Australia,

At the time the American Constitution was framed, the framers of that Constitution had in mind certain events which they wished never to be repeated, and which never will be repeated in our civilisation. $\underline{78}$

Symon from South Australia also agreed with Braddon. He was in favour of the idea of the preservation of freedom of religion but thought the means inappropriate: "a prohibition against the state and against the Commonwealth making any law prohibiting the free exercise of any religious faith is, I think, a little beyond what any of us is prepared to go". $\underline{79}$

As well as these objections, there were Barton's and Downer's claims that the amendment was unnecessary, given that the Commonwealth had no power over religion in the first place. Combined with the concession by Higgins that the prohibition should extend only to the Commonwealth and not the States, on the premise that upon federation the States were to retain the residual powers, the amendment as well as a Tasmanian clause prohibiting the support of any religion was negatived. As a result the clause itself was struck out. $\underline{\underline{80}}$

Later in the Convention Higgins introduced a new clause that would limit the Commonwealth's powers regarding religion. The new provision was not meant to change the law, according to Higgins; it was only an attempt to make sure that, given the reference to the Almighty in the preamble, no-one would think that the status quo had altered:

I simply want to leave things as they are. I do not want to interfere with any right the state has. I merely want to make it clear that, having inserted in the preamble of the Constitution certain words which, according to the United States precedents, would involve certain inferential powers, there is no intention on the part of the Convention to confer even inferentially these powers on the Federal government. $\underline{81}$

The measure was therefore no more than a confirmation of the existing law and its recognition in the new Constitution. It may have limited the actions of Federal Parliament but in no sense did it attempt to control the States. On the grounds that the section would clear away doubts and allay any apprehensions, Symon, Wise, Kingston, and Lyne spoke in favour of the provision. ${ }^{82}$ It was, as Wise called it, a "solatium" for those who were concerned that the preamble might allow the Commonwealth to enact Sunday observance laws.

The speeches revealed that the there was no great concern that Parliament would in fact enact what was 
thought to be such improper legislation. As Barton quickly pointed out, if this was the problem then it made no sense to fear the Commonwealth and not the States. Barton's speech indicated why he opposed the measure:

The whole of the advancement in English-speaking communities, under English laws and English institutions, has shown a less and less inclination to pass laws for imposing religious tests, or exacting religious observances, or to maintain any religion.

If I thought there was any - the least - probability or possibility, taking into consideration the advancement of liberal and tolerant ideas that is constantly going on, of any of these various communities utterly and entirely retracing its steps, I might be with the honourable member. $\underline{\underline{83}}$

Barton's concern was that the clause would prohibit the Commonwealth from legislating on "practices in various religions which are believed in by persons who may enter into the Commonwealth belonging to other races, which practices would be totally abhorrent to the ideas, not only to any Christian, but to any civilised community". .84 The Commonwealth should have the power to prevent "outrages on humanity and justice".

That the provision was enacted as a solatium, to assuage fears that the status quo had not been altered by the changes to the preamble, combined with the observation that the States retained the power to enact legislation affecting religion, suggests that most shared Barton's view that neither the State nor the Commonwealth Parliaments were a threat to religious freedom. As Symon claimed, "under the operation of the common law any inhumanities and cruelties could be effectually stopped". $\underline{85}$

\section{Privileges and immunities, due process, and equal protection}

The provision as it was originally drafted in Sydney in 1891 was aired at some length in the Melbourne Convention and, after a confusing and wandering debate, the proposed provision, as well as the more extensive amendments, were struck out altogether. $\frac{86}{}$ Subsequently, the debate was renewed resulting in the adoption of the clause as section 117 of the Constitution. ${ }^{87}$ The discussion on the merits of this provision went to the core of the problem of the different understandings of rights, and the sources of such understandings, because the delegates in the course of the debates effectively provided a commentary on the privileges and immunities, due process and equal protection clauses. By examining these arguments, it is possible to present the range of views held by the founders regarding the protection and preservation of individual liberties.

When the clause was first debated in Melbourne it was evident that there was great uncertainty as to its meaning. Carruthers, a future Premier of New South Wales, submitted that the Legislative Assembly of New South Wales had suggested that the reference to privileges and immunities be struck out because they could not understand it. He regarded states as having complete jurisdiction in their sphere and therefore could not understand how privileges and immunities could be "carried" by a citizen. "When he 
divests himself of the jurisdiction of a state and takes upon himself the jurisdiction of another state the laws of the former will have no force and effect outside its boundaries". $\underline{88}$ This touched upon the more fundamental question of citizenship which formed the core of the subsequent debate regarding privileges and immunities. The debate was made even more complex by the proposal of the Tasmanian House of Assembly to replace the section with the equivalent of the Fourteenth Amendment, incorporating due process and equal protection provisions. The host of questions and difficulties raised in the course of the debates indicates the unfamiliarity of these measures and their principles to the founders.

Those who were in favour of including a privileges and immunities guarantee saw it as a way to stop a State discriminating against citizens on the grounds of residence. For Wise the danger was discriminatory legislation such as a poll tax, extra probate duty, or an absentee tax that would affect the property of non-State residents. Yet he had considerable difficulty in explaining how these interests were privileges or immunities. ${ }^{\frac{89}{}}$ He put the problem in terms of a common Australian citizenship:

It is a survival of the old idea that there is a distinctive citizenship in a Victorian, and a distinctive citizenship in a New South Wales man. That is the idea which I am endeavouring to destroy by supporting the amendment of Tasmania, that Australian citizenship, and that alone, shall be recognised in every part of the Federation. $\underline{90}$

Wise was supported by Kingston, Symon, and Glynn; however, each had a different view of the implications of the section with respect to citizenship, which further complicated the debate, because there was no clear understanding as to the meaning of citizenship. Kingston, Premier of South Australia, agreed with Wise that there should be a federal citizenship. Symon wanted to protect federal citizenship but rejected the proposal that there should be any interference with the "control on the part of each state of its own citizens"..$\underline{1}$ Glynn proposed a "universal citizenship both as regards the Commonwealth and as regards the states". $\underline{92}$

As noted above, some opposed the clause simply because they did not know its meaning. Others saw it as a measure adopted from an American precedent that was inappropriate to the Australian situation. Isaacs referred to the origins of the clause in the Fourteenth Amendment and stated that it was a specific provision for the unique problem of slavery in the United States and did not concern Australia. $\frac{93}{3}$ He was supported by Barton, O'Connor and Cockburn. For Forrest, the Premier of Western Australia, the clause had the potential to limit legislation that was enacted on the basis of race or colour. Western Australian legislation prohibiting Asians or Africans from obtaining miners' licences would be struck down. Until the introduction of uniform federal legislation based on race, Forrest advocated the retention of State powers to legislate on these matters. $\frac{94}{}$ Reid, Premier of New South Wales, objected to the measure on similar grounds that it would limit State rights, something that was contrary to the very terms of federation. $\frac{95}{}$ It was not clear whether there was a true meeting of minds on the substance of the proposals made by the supporters of the clause. This would take place in the re-introduction of the provision by Symon. 
There was, however, further debate on the merits of the Tasmanian proposal to incorporate the equivalent of the Fourteenth Amendment. As well as the privileges and immunities clause, the Convention also considered the merits of the due process and equal protection clauses of the section. O'Connor wanted to retain the due process and equal protection clauses "so that any citizen of any portion of the Commonwealth would have the guarantee of liberty and safety in regard to the processes of law, and also would have a guarantee of the equal administration of the law as it exists". $\underline{96}$

Isaacs opposed O'Connor's proposal to insert a clause that would not allow a state to deprive a person of life, liberty or property without the due process of the law. He saw no necessity for such a clause because "under our state Constitution no attempt has ever been made to subject persons to penalties without due process of law". These words "can only mean the process provided by the state law. If they mean anything else they seriously impugn and weaken the present provisions of our Constitution".

O'Connor justified such an amendment on the basis that:

In the ordinary course of things such a provision at this time of day would be unnecessary; but we all know that laws are passed by majorities, and that communities are liable to sudden and very often to unjust impulses - as much so now as ever. The amendment is simply a declaration that no impulse of this kind which might lead to the passing of an unjust law shall deprive a citizen of this right to a fair trial. $\underline{98}$

The ensuing debate reveals the different views held by the other delegates. Kingston wanted to know what was meant by "due process of law". .99 O'Connor responded that it meant the proper administration of the laws. Symon stated that this was ensured by the various State Constitutions. O'Connor noted the necessity of securing such a right so that State Constitutions would not be amended. Symon referred to the protection allowed under the Magna Charta. O'Connor responded that the States may repeal the Magna Charta - "I admit we are only dealing with a possibility, but at the same time it is a possibility which if it eventuated, as it might, would be very disastrous, and there is no reason why we should not prevent it". $\underline{100}$

A similar debate took place between O'Connor and Cockburn. Cockburn rejected the proposal because it "would be a reflection on our civilisation. Have any of the colonies of Australia ever attempted to deprive any person of life, liberty, or property without due process?" He went further by arguing that the "only country in which the guarantee exists is that in which its provisions are most frequently violated". Isaacs stated that a statement of this sort "is an admission that it is necessary", while Gordon asked, "Might you not as well say that the states should not legalise murder?". $\frac{101}{1}$

It is important to note that while O'Connor appeared to support the "proper administration of justice", in fact he favoured a notion of "substantive due process". Initially it appeared that both parties agreed as to the ends and that at issue was the efficacy of the means - O'Connor arguing that the measure was needed and at the least it was harmless, the others arguing that it was at best insulting, at worst useless since 
such protections assumed communal goodwill in any case. However, at a deeper level it was a question as to how each party understood the dynamics of human progress and advancement. O'Connor appeared to rely on contract - reason that showed itself in agreement - to secure liberty. The others also relied on reason but of a different dimension - reasonable action having its source in communal goodwill, history and tradition. The fundamental differences between the two positions in terms of human nature and the progressive spirit of the law was therefore not really confronted in the course of the debates.

The equal protection clause received even less consideration. Isaacs stated that the clause had been enacted in the United States to overcome discrimination based on race or colour. As such the clause would void discriminatory factory legislation, and therefore risk losing the support of workers for the Constitution. Moreover, he argued that such legislation could affect the concurrent power given to the States under the special race power of the Commonwealth. In light of this and of the lengthy debate regarding the effect of the privileges and immunities clause on the question of race, the equal protection clause did not receive any more attention. $\underline{102}$

By the end of the debates the original provision was struck out and an amendment to include a due process or equal protection provision was rejected. The entire discussion was unsatisfactory and confusing, with many different proposals and amendments on the table so that it is difficult to see what was being discussed. In any case, the proposed amendments appeared foreign to the delegates, raising complex problems of citizenship, race and State rights. There was a general reluctance on the part of the delegates to agree to these measures; to them they seemed either obvious, pointless or, at worst, potentially confusing if not insulting. The debates confirm the gulf that separated the founders from these notions of privileges and immunities, due process and equal protection of the laws.

Some time after the clause was struck out, Symon reintroduced a modified clause that provided: "The citizens of each state shall be entitled to all privileges and immunities of citizens in the several states". Symon's primary concern was that a state should not discriminate on the basis of residence; it was otherwise to be free in legislating according to the powers it would have under federation. As O'Connor made clear towards the end of the debate, the only thing provided by the clause was "that there should be no power in a state to treat the inhabitants of another state differently from its own". ${ }^{103}$ Clark too saw the mischief to be overcome as the enactment by the States of legislation that may interfere with freedom of trade. $\frac{104}{}$ Those in favour of the clause saw it in essence as a measure that would protect individuals from discriminatory legislation. However, the impugned form of discrimination was discrimination based on residence. As the measure attempted to secure interstate dealings, it was in essence an attempt to secure better or more consistent terms for federalism.

Although the principle that States would no longer be allowed to discriminate on the basis of a person's residence appeared clear enough, the attempt to enact it in terms of privileges and immunities of citizens produced a great deal of confusion and along the way, disclosed what the founders conceived to be the appropriate grounds for discrimination. 
The problem at its core concerned the notion of what a citizen is and what constitutes citizenship. The delegates did not understand what a "citizen" was. "What is a citizen? A British subject?" asked Forrest. For Barton,

We are subjects in our constitutional relation to the empire, not citizens. "Citizens" is an undefined term, and is not known to the Constitution. The word "subjects" expresses the relation between citizens of the empire and the Crown. $\underline{105}$

The founders viewed themselves primarily and fundamentally as subjects, loyal to the Crown and Empire and not as citizens as such. All their rights and entitlements derived from, and had as their source, Britain and the Queen. This view was at some distance from the conception of citizen as deriving rights and liberties from nature, if not from the self-imposed obligations of a republic constituted by the people itself.

The reference to "citizen" in the proposed amendment led to the complex question of defining citizenship itself. Quick's proposed definition - "All persons resident within the Commonwealth, being natural-born or naturalised subjects of the Queen, and not under any disability imposed by the Parliament, shall be citizens of the Commonwealth" - was rejected for a number of reasons. Holder, the former Premier of South Australia, objected that who is a citizen is matter that should be left for Parliament to determine from time to time. Isaacs observed that such a definition would limit legislation based on race; race could never be a disability in the same class as infancy or lunacy. Ironically, the debate revealed a great concern by many of the delegates that racial legislation should not be affected by the clause. Wise's suggested amendment - that the "section shall not apply to the people of any race" in respect to which the Commonwealth might exercise its power - reveals the extent of the concern. He was certainly not alone in this matter. The delegates argued in favour of racial discrimination on a number of different but related grounds, ranging from the practical concerns of having the Constitution accepted to more obvious racial differences. ${ }^{106}$ It is important to recall that the Commonwealth was allowed the power under the Constitution to make laws with respect to immigration and emigration (51 (xxvii)) and "people of any race" (51 (xxvi)). The privileges and immunities clause, as it applied to racial differences, appeared to undermine this power.

The other difficulty with the proposed amendment concerned its reference to privileges and immunities. Rather than securing protection from discrimination based upon residence, it in fact appeared to allow individuals to claim in another state all the privileges and immunities they had in their own; not only regarding property rights and the rights of absentee landlords, but also, by logical extension, the benefits of electoral laws and therefore citizenship. It would impose a common citizenship as defined by the state which had the most inclusive or widest definition of what was a citizen. $\frac{107}{}$ Therefore, the discussion returned to the confused debate concerning citizenship. But this time it also raised the important question of State rights - if federation was meant to leave the States with most of their powers, did not such a provision restrict State freedom improperly? What of the Commonwealth power to legislate with respect to race? Would this not override inconsistent State legislation? 
Towards the end of the debate it was evident that what was intended by the amendment was not reflected in the terms of the clause; in fact the words used in the section were either foreign to the delegates or went too far in defining a common citizenship and disallowing certain forms of discrimination. Consensus was reached only when all these terms - citizen, privileges, immunities - were simply dropped.

The clause that was adopted as section 117 was free from such ambiguities, announcing in its very terms the considerable distance that separated it from the American models upon which it was originally premised.

\section{Convention debates and the founders' intention}

The investigation of the convention debates above allows us to make some tentative observations with respect to the principles and ideas that informed the founders' vision of rights and liberalism. Foremost is the crucial importance of Parliament for the founding fathers. As far as possible Parliament was to have unrestricted authority, untrammelled by any constitutional limitations. Parliament's hands were not to be tied because it represented the primary means for addressing political problems as they emerged. Though some fears were expressed of sudden and unjust impulses of majorities, in general Parliament was not regarded as a threat to liberties. There were a number of reasons for this.

The first was the belief that liberty was threatened not by Parliament - which represented the will of the people - but by the Executive. Accordingly, provided responsible government and the rights of representation were secure, Parliamentary supremacy and the rule of law through the Courts would ensure the safety of traditional freedoms. Why then not protect and guarantee freedoms by writing them down and entrenching them in a Constitution? Primarily because this misconceived the way freedoms were secured, assuming that there was security in contracts. $\frac{108}{}$ But precisely because community was not an artificial, contractual agreement for the protection of natural rights, it was inappropriate to limit Parliament by using such measures. These rights and freedoms were those of Englishmen, the heritage of the ancient constitution as well as conventions and traditions that had developed over time. They were rights of subjects, not the abstract rights of "nature" let alone those of general "humanity".

This argument, that drew upon Burkean prescriptive rights, coexisted with a modified Benthamite notion of utilitarian progress. $\frac{109}{}$ The founders consistently rejected the view that Parliament should be limited. It was insulting to prescribe limits to Parliament because it presumed that regressive measures were within its contemplation. Human beings were evolving and developing, moving from barbarism and intolerance to enlightenment and civilisation. Thus to entrench rights was either to assume progress was questionable or to hobble and limit its future development by restricting it to current notions of what was possible.

The attempt to entrench an extensive range of rights in the Constitution proved to be unsuccessful. If federalism was an innovation that was not fully understood but nevertheless accepted as a necessary solution for the difficulties faced by the Colonies, the inclusion of specific rights appeared simply 
foreign to the founders and decisively unnecessary. The rights were retained in the Constitution only because they were consistent with federalism, or as a harmless confirmation of what was already accepted. The sum effect of these provisions was that the Federal government had some limitations placed upon it while the States would not be able to discriminate on the grounds of State residence. Practically and philosophically this was indeed at some distance from a constitutionally entrenched bill of rights.

\section{ORIGINALISM AND THE "DEAD HAND" OF THE FOUNDERS}

What implications do these observations have for the High Court's jurisprudence of rights? The question of original intent has to date exercised a much more important philosophical and political role in American, as opposed to Australian, jurisprudence. $\frac{110}{}$ However, as the Court moves away from its traditional literalism and legalism to articulate a new basis for the interpretation of the Constitution, the question of originalism will assume a more prominent role. 111

The discussion above regarding rights and the founders' understanding of liberalism underlines the fact that, for the founders, the Commonwealth Constitution was no more than a skeletal structure that was to accommodate a growing and changing body politic. The Constitution was not meant to restrain the progressive, civilising development of Australian liberal democracy. Accordingly, Parliament was entitled to a substantial degree of freedom in pursuing the common good as it saw it. Therefore, far from being the "dead hand" of the past, originalism in fact allows the greatest scope for political experimentation and innovation. $\frac{112}{2}$ This would suggest, however, that just as the founders did not favour express rights they would not have supported the Court's implied rights jurisprudence. The Constitution is to have a "living force," yet the substance, meaning and direction of this force is to be given by Parliament and not by a "progressivist" judiciary. $\frac{113}{2}$ In other words, the judiciary is not entitled to endow the Constitution with a meaning that neither the founders nor the people intended. $\underline{114}$

It seems clear, then, that originalism will tend to restrain judicial activism. However, it is arguable that, by adopting a different perspective on the founders' understanding of progress and liberalism, it may be possible for originalism in Australia to accommodate a more activist judiciary. The founders' notion of progress outlined above emphasises the apparently uncertain direction advancement will take, and therefore suggests that future generations should be entitled to fix the contours of liberalism as they see fit. To the extent that the founders regarded choice and experimentation as essential for progress this view nicely captures their vision of liberalism. However, this perspective tends to obscure another important dimension to their understanding of progress. For the founders, progress was also an ascent or a climb whereby in time what was contested became accepted as truth. Progress tended to build on past achievements rather than undertaking radical and fundamental change. This meant in effect that some matters such as parliamentarianism, religious toleration and freedom of speech were no longer subject to dispute, forming a part of the fabric of the law, either as specific provisions or unwritten conventions. This view suggests that, no matter how open to social and political experimentation, it is difficult to deny that the founders shared and intended to secure a certain vision of liberalism. 
Now to the extent that the Constitution takes its meaning from, and is informed by, these conventions, traditions and unwritten and evolving principles of political life, the founders' original intent arguably favours a jurisprudence that interprets the Constitution in the light of the principles animating it as a whole. The founders would favour the Court's implied rights jurisprudence where the Court is merely exercising its traditional role of upholding the rule of law understood in its broadest sense. $\frac{115}{}$ Thus originalism makes it possible for the Constitution, and therefore the judiciary, to protect fundamental liberal principles while accommodating an evolutionary notion of liberalism. $\frac{116}{}$ Consequently, this view of progress makes it possible for originalism in Australian jurisprudence, contrary to its influence in America, to support a more expansive role for the judiciary.

To be sure this notion of progress raises profound philosophical and political difficulties which cannot be taken up here. For example, what happens when the founders' notion of evolution, progress and civilisation is no longer accepted as a valid foundation for liberalism? $\frac{117}{2}$ What happens when the polity moves towards a liberalism based on nature or humanity? $?^{118}$ These difficulties suggest that the question of original intent cannot help but become a more profound question of the founders' vision of liberalism, a question difficult to address and explore in the course of constitutional adjudication.

\section{CONCLUSION}

The paper started with the observation that the High Court is now prepared to give greater authority to historical sources in the interpretation of the Constitution. I have suggested that this apparently small step in the way the Court is to interpret the Constitution may have significant consequences for Australian constitutionalism.

Either as the dead hands of the past or the living force of the present, it is difficult to deny that the founders' intention will increasingly influence, if not shape, political, philosophical and jurisprudential debate in Australia.

\section{FOOTNOTES}

1 * B Econ, LLB (Qld); MA, PhD (Toronto); Lecturer, School of Politics and Public Policy, Griffith University.

2 Attorney-General (Cth); ex rel McKinlay v Commonwealth (1975) 135 CLR 1, at 17 per Barwick CJ, at 47 per Gibbs J; Attorney-General (Cth) v T \& G Mutual Life Society Ltd (1978) 52 ALJR 573, at 583 per Aickin J; Attorney-General (Vic); ex rel Black v Commonwealth (1981) 146 CLR 559, at 578 per Barwick CJ, at 167 per Gibbs J. See P Brazil, "Legislative History and the Sure and True Interpretation 
of Statutes in General and the Constitution in Particular" (1961) 4 UQLJ 1; J Thomson, "Constitutional Interpretation: History and the High Court: A Bibliographical Survey" (1982) 5 UNSWLJ 309; M Coper, "The Place of History in Constitutional Interpretation" in G Craven (ed), The Convention Debates 18911898: Commentaries, Indices and Guide (1986) 5; H Burmester, "The Convention Debates and the Interpretation of the Constitution" in G Craven (ed), The Convention Debates 1891-1898:

Commentaries, Indices and Guide (1986) 25; C McCamish, "The Use of Historical Materials in Interpreting the Commonwealth Constitution" (1996) 70 ALJ 638.

3 Thus the Court's literalism and legalism has influenced the nature of extrinsic material that could be consulted. Note also that there are other arguments for rejecting historical materials such as the lack or inaccessibility of such material, as well as the difficulty of establishing such an intention due to the different opinions voiced in the course of the debates, the fact that the debates are silent on many issues and that in a number of instances the enactments were compromises.

4 The exception was confined to the draft bills of 1891, 1897 and 1898. Tasmania $v$ Commonwealth (1904) 1 CLR 329 at 333 per Griffith CJ; Seamen's Union of Australia v Utah Development Co (1978) 53 ALJR 83 at 92 per Stephen J.

5 Municipal Council of Sydney v Commonwealth (1904) 1 CLR 208, at 213-4 per Griffith CJ.

6 G Craven, "The Crisis of Constitutional Literalism in Australia" in H P Lee and G Winterton (eds), Australian Constitutional Perspectives (1992) 1.

7 Cole v Whitfield (1988) 165 CLR 360 at 385.

8 New South Wales v Commonwealth (1990) 169 CLR 482.

9 See G Craven, above n 5 at 22.

10 Australian Capital Television Pty Ltd v Commonwealth (1992) 177 CLR 106; Nationwide News Pty Ltd v Wills (1992) 177 CLR 1; Theophanous v Herald and Weekly Times Ltd (1994) 182 CLR 104; Stephens v West Australian Newspapers Ltd (1994) 182 CLR 211; Cunliffe v Commonwealth (1994) 182 CLR 272.

11 The founders' understanding of federalism is explored by $\mathrm{J}$ Warden, "Federalism and the Design of the Australian Constitution" (1992) 27 AJPS 143. For writings on the history of particular sections see generally J Thomson, above $\mathrm{n} 1$, Appendix A.

12 The exceptions to this concern the changes made in London in 1900 especially regarding appeals to the Privy Council. See J La Nauze, The Making of the Australian Constitution (1972) ch 16. For accounts of federation by the founders or their contemporaries see J Quick and R Garran, The Annotated Constitution of the Commonwealth of Australia (1901); A Deakin, The Federal Story (1944); W H 
Moore, The Constitution of the Commonwealth of Australia (2nd ed 1902); B Wise, The Making of the Australian Commonwealth (1913). For a more contemporary account see L Crisp, Federation Fathers (1988).

13 For example, the resolutions proposed by Parkes at the Sydney Convention in 1891.

14 A Deakin, above n 11 at 45 stated that the question of responsible government and the Senate veto over money bills "severed the Convention into two camps". See also B Wise, above n 11 at 125; J La Nauze, above $n 11$ at 43 and 139-160.

15 According to Hackett there were two alternatives - "either responsible government will kill federation or federation in the form in which we shall, I hope, be prepared to accept it, will kill responsible government": Volume 1, Official Record of the Proceedings and Debates of the Australasian Federal Convention, (Convention Debates) Sydney, 1891, 280.

16 Cockburn, Convention Debates, Sydney, 1891, 198.

17 See B Galligan, "Parliamentary Responsible Government and the Protection of Rights" (1993) 4 PLR 100.

18 Some commentators include in this list equal voting rights (ss 24,25$)$, the right to vote (s 41 ), freedom of interstate trade (s 92), non-discrimination regarding Commonwealth taxes and bounties (ss 51 (ii), 51(iii) as well as ss 86, 88 and 90), the inconsistency provision (s 109) and the full faith and credit requirement (s 118). See the judgment of Deane J in Street v Queensland Bar Association (1989) 168 CLR 461 at 521, where he endorses such a wider reading of rights.

19 See, however, M Howard and J Warden (eds), An Australian Democrat: The life, work and consequences of Andrew Inglis Clark (1995); J Warden, above n 10; B Galligan, "Judicial Review in the Australian Federal System" (1979), 10 FLR 367 at 374-378; R Ely, "Andrew Inglis Clark and the Church-State Separation" (1975) 8 Journal of Religious History 271; J La Nauze, above n 11; J Neasey, "Andrew Inglis Clark Senior and Australian Federation" (1969) 15 Australian Journal of Politics and History 1; J Reynolds, "A. I. Clark's American Sympathies and his Influence on Australian Federation"(1958) 32 ALJ 62; J Williams, "'With Eyes Open': Andrew Inglis Clark and Our Republican Tradition" (1995) 23 F L Rev 149.

20 A copy of the draft may be found in J Reynolds, above n 18 at 67-75.

21 J Neasey, above n 18 at 7-8. Neasey also provided a useful comparative table comparing Clark's Bill with its Canadian and American equivalents.

22 Clark cited in J Neasey, above n 18 at 8. 
23 He visited the United States in 1890, 1897-8, and again in 1902-3. During his first trip he met Oliver Wendell Holmes Jr who was very influential on his thinking. Holmes also introduced him to a number of professors at Harvard. See J Reynolds, above n 18 at 65-66.

24 A Deakin, above n 11 at 30.

25 J Reynolds, above n 18.

26 Clause 17 read: "A State shall not make or enforce any law abridging any privileges of citizens of other States, nor shall a State deny to any person within its jurisdiction the equal protection of the laws".

27 See the discussion below of the drafting history of s 117 as well as J La Nauze, above n 11 at 227231. J Thomson, "Andrew Inglis Clark and Australian Constitutional Law" in M Howard and J Warden (eds) above n 18 at 69-72, argues that Clause 59 of Clark's Bill, which vested judicial power in the High Court and the federal courts constituted in effect a prohibition on Commonwealth ex post facto criminal laws. See also F Neasey, "Andrew Inglis Clark and Federation after 1891" in M Howard and J Warden (eds) above $\mathrm{n} 18$ at 40.

$28 \mathrm{~J}$ La Nauze, above n 11 at 227, refers in particular to the guarantees against the quartering of soldiers and cruel and unusual punishment.

$29 \mathrm{~J}$ Thomson, above n 26 supports this interpretation.

30 The Tasmanian amendment read: "The citizens to each State, and all other persons owing allegiance to the Queen and residing in any territory of the Commonwealth shall be citizens of the Commonwealth, and shall be entitled to all the privileges and immunities of the citizens of the Commonwealth in the several States, and a State shall not make or enforce any law abridging any privilege or immunity of the citizens of the Commonwealth, nor shall a State deprive any person of life, liberty, or property without due process of law, or deny to any person within its jurisdiction the equal protection of the laws". Convention Debates, Melbourne, 1898, 664-691. See also J La Nauze, above n 11 at 231.

31 See H Storing, What the Anti-Federalists Were For (1981) at 64-70; L Tribe, American Constitutional Law (2nd ed 1988).

32 As late as the Slaughter-House cases, 83 US (16 Wall) 36 (1873), the Court held that laws enacted by the Louisiana legislature establishing a slaughterhouse monopoly did not violate the Fourteenth Amendment's privileges and immunities clause.

33 L Tribe, above $n 30$ at 560-586. The so called "Lochner era," according to Tribe, "reigned in the period beginning around the turn of the century with Allgeyer and ending by the middle of the 1930's with West Coast Hotel v Parrish": ibid at 567. Which is not to deny the importance of natural law arguments: see L Tribe, ibid at 560-567. 
34 It became more and more important in the course of the convention debates for the founders to demonstrate their knowledge of comparative constitutional law and in particular that of the United States.

35 For reference to Bryce in the Convention debates see, for example, Convention Debates, Sydney, 1891, 147 (Rutledge), 210 (Brown), 545 (Baker), 597 (Kingston); Convention Debates, Sydney, 1897, 56 (Deakin); Convention Debates, Melbourne, 1898, 374 (Symon).

36 In J La Nauze, above n 11 at 19. Deakin had met Bryce in London in 1887 and rated the American Commonwealth in these terms: "As a text-book for the philosophic study of constitutional questions it takes its place in the very first rank".

37 J La Nauze, ibid at 87.

38 Ibid at 273. La Nauze described the work in these terms: "It was quoted or referred to more than any other single work; never criticised, it was regarded with the same awe, mingled with reverence, as the Bible would have been in an assembly of churchmen". There was no comparable work on the Canadian federation.

39 For Bryce's notion of federalism in general see J Warden, n 10 above.

40 According to Bryce the notion of flexible and rigid constitutions was intended to replace the previous distinction between written and unwritten constitutions. See J Bryce, Studies of History and Jurisprudence (1901), at 145-254.

41 J Bryce, The American Commonwealth (2nd ed 1919) at Vol 1, 367.

42 Ibid at 368. He argued that they were "indispensable to the reconstruction of the Federal system".

43 Ibid at 438.

44 Ibid.

45 Ibid.

46 J Bryce, Studies of History and Jurisprudence at 502-3. See also C Pannam, "Travelling Section 116 with a U.S. Road Map" (1963) 4 MULR 41 at 46-7. According to Bryce, Canada and Australia followed the English model: "So when Englishmen in Canada or Australia enact new Constitutions, they take no heed of such matters, and make their legislature as like the omnipotent Parliament of Britain as they can": ibid at 502. The exception in the Australian case "which recalls the old-fashioned Bill of Rights" 
was section 116. For a discussion of the Canadian case see R Risk and R Vipond, "Rights Talk in Canada in the Late Twentieth Century: 'The Good Sense and Right Feeling of the People'" (1996) 14 Law and History Review 1.

47 J Bryce, above n 40 at 345.

48 This was consistent with federalism and democracy according to Bryce. This was the natural process from the "maladies of youth" to the "settled health of manhood". Bryce, ibid at 339-340.

49 The states allow for "safe" experimentation and diversity, just like so many water-tight compartments in a ship: Bryce, ibid at 350-355.

50 J La Nauze, above n 11 at 20. See for example Convention Debates, Sydney, 1891, 105 (Downer), 198 (Cockburn); Convention Debates, Adelaide, 1897, 307 (M Clarke), 911 (Barton); Convention Debates, Melbourne 1898, 1686 (Gordon), 1686 (Wise), 1897 (Isaacs).

51 A V Dicey, Introduction to the Law of the Constitution (8th ed [1915] 1982) at 107-122.

52 For more recent and well known instances see Sir Owen Dixon, "Address at the Annual Dinner of the American Bar Association" (1942) 16 ALJ 192; R Menzies, Central Power in the Commonwealth (1967).

53 Quick represented Victoria in the 1897-98 Conventions and Garran was secretary of the Drafting Committee. See for example the dismissive reference in the discussion of section 116: "The prohibition contained in the first amendment was one of the ten articles in the so-called 'American Bill of Rights' adopted after the establishment of the Union, in order to satisfy popular demands and sentiments" : $\mathrm{J}$ Quick and R Garran, above n 11 at 952.

54 Ibid at 957.

55 W H Moore, above n 11 at 612-16.

56 Section 51(xxxi) provides: "The Parliament shall, subject to this Constitution, have power to make laws for the peace, order, and good government of the Commonwealth with respect to: - The acquisition of property on just terms from any State or person for any purpose in respect of which The Parliament has power to make laws".

57 Convention Debates, Melbourne, 1898, 151. Wise had noted the need for such a provision in the Adelaide Convention: "I do not think there is power either expressly or impliedly given to construct within the boundaries of any State such public works with the consent of that State as may be for the common advantage of the whole Commonwealth": Convention Debates, Adelaide, 1897, 1199. 
59 Ibid at 151.

60 Ibid at 153.

61 Isaacs requested further time on the grounds that a compulsory acquisition power potentially against the will of the state reversed the principle that "a state should not be compelled to give up its territory": ibid.

62 Convention Debates, Melbourne, 1898, 1874.

63 See s 65 of Clark's original draft in J Reynolds, above n 18 at 73. See also C Pannam, "Trial by Jury and Section 80 of the Australian Constitution" (1968) 6 Syd LR 1 at 1, 2-4.

64 Ch. III, cl 11; Convention Debates Sydney, 1891, 958.

65 Convention Debates, Melbourne, 1898, 353, 1895.

66 Convention Debates, Adelaide, 1897, 991.

67 Convention Debates, Melbourne, 1898, 350, 353.

68 "It does not interfere with the right of every state to alter its laws and to deprive its citizens of their liberty of being tried by a jury of their fellow countrymen, but it does say that the Federal parliament shall be compelled to submit any person accused of a breach of the federal laws to trial before a body of his own fellow citizens in the state to which he belongs". Convention Debates, Melbourne, 1898, 350.

69 Ibid at 351.

70 Ibid at 1894-5.

71 See R Ely, Unto God and Caesar: Religious Issues in the Emerging Commonwealth 1891-1906 (1976); S McLeish, "Making Sense of Religion and the Constitution: A Fresh Start for Section 116" 18 Monash University Law Review 207; and the references in J Thomson, above $\mathrm{n} 1$ at 326.

72 The original section read "A State shall not make any law prohibiting the free exercise of any religion". See Convention Debates, Sydney, 1891, 962; Convention Debates, Adelaide, 1897, 1004.

73 Convention Debates, Melbourne, 1898, 654. 
74 Though initially unsuccessful, Glynn's proposal to recognise the Almighty in the preamble was adopted by the Convention. As he noted in his diary (cited in R Ely, above at $n 70$ at 74) "Today I succeeded in getting the words 'Humbly relying on the Blessing of Almighty God' inserted in the preamble. It was chiefly intended to secure greater support from a large number of voters who belie[ve] in the efficacy for good of this formal act of reverence and faith". See also S McLeish, above n 70 at 2189.

75 See R Ely, above n 70 at 21-30.

76 Ibid at 656. He did, however, indicate that same safeguard in the Constitution might be necessary if the recent trend in governmental interference in economic matters was extended to other areas.

77 Ibid at 657. He had in mind such practices as "suttee" which he called "simply murder".

78 Ibid at 660, 662. This faith in the progressive nature of civilisation was questioned by Barton who raised the possibility of "throwing back" - his specific reference was to the revival of sumptuary laws but he did suggest that it might be useful to preserve the free exercise of religion in the Constitution.

79 Ibid at 659. "We are living in a very advanced age not in medieval times".

80 Ibid at 664.

81 Ibid at 1769. Higgins referred to a decision of the Supreme Court of the United States that suggested that America is a Christian country. However, as C Pannam, "Travelling Section 116 with a U.S. Road Map" (1963) 4 MULR 41 at 53 noted, the Court's decision, which presumably was The Church of the Holy Trinity v United States 143 US 457 (1882), did not support this view.

82 Ibid at 1769-79.

83 Ibid at 1771.

84 Ibid. Barton stated that such practices might be controlled by the Commonwealth under its emigration, naturalisation and race powers. See also the references by Fraser to "homogeneous people": ibid at 1775.

85 Ibid at 1776. See, however, Wise's concern that "we have seen in our own time a recrudescence of that evil demon, which I fear, is only scotched and not killed. At any rate, the period during which we have enjoyed religious liberty is not long enough for us to be able to say with confidence that there will be no swinging back of the pendulum to the spirit of the times from which we have only recently emerged": ibid at 1773. 
86 The text of the Bill that was agreed to but not discussed at the Conventions until Melbourne read: "A State shall not make or enforce any law abridging any privilege or immunity of citizens of other States of the Commonwealth, nor shall a State deny to any person, within its jurisdiction the equal protection of the laws". The relevant provisions in the American Constitution are Art IV, section 2: "The Citizens of each State shall be entitled to all the Privileges and Immunities of Citizens in the several States"; and the Fourteenth Amendment, the first section: "All persons born or naturalised in the United States, and subject to the jurisdiction thereof, are citizens of the United States and of the State wherein they reside. No State shall make or enforce any law which shall abridge the privileges or immunities of citizens of the United States; nor shall any State deprive any person of life, liberty or property, without due process; nor deny to any person within its jurisdiction the equal protection of the laws". See C Pannam, "Discrimination on the Basis of State Residence in Australia and the United States" (1967) 6 MULR 105 at $105-116$.

87 Section 117 reads : "The subject of the Queen, resident in any State, shall not be subject in any other State, to any disability or discrimination which would not be equally applicable to him if he were a subject of the Queen resident in such other State".

88 Convention Debates, Melbourne, 1898, 666.

89 Isaacs in particular was not persuaded that Wise could call such measures privileges and immunities and, under questioning, Wise had considerable difficulty in using this terminology: ibid at 671 .

90 Ibid at 675.

91 Ibid at 677.

92 Ibid at 680 .

93 He refers to the Slaughter House cases as well as Strauder v State of West Virginia 100 US 303 (1879).

94 Convention Debates, Melbourne, 1898, 665.

95 Ibid at 675.

96 O'Connor argued that the privileges and immunities clause would be unnecessary because the federal government would be able to legislate on "aliens and coloured races". Barton supported his proposed amendment to provide for due process and equal protection: ibid at 673.

97 Ibid at 687-88. 
98 Isaacs' response is telling: "That is a very dangerous proposal - that the Supreme Court should control the Legislatures of the states within their own jurisdiction": ibid at 683.

99 "It seems to me to be a matter of purely state concern, and which, at this period of the nineteenth century, it is seriously suggested may be necessary, in order to prevent some high-handed and monstrous action on the part of the states, for which our past history gives no grounds for expectation": ibid at 678 .

100 Ibid at 683.

101 Ibid at 682-4.

102 Ibid at 686-8.

103 Ibid at 1796.

104 Wise quoted from Clark's memorandum which referred to the United States examples where taxes were placed on commercial travellers and on limitations on actions for damages enacted by the state of Maine: ibid at 1793.

105 Ibid at 1786.

106 Forrest was primarily concerned with the validity of the Western Australian legislation that discriminated against Chinese miners. Braddon wanted to adopt the Tasmanian proposal which is the equivalent of the American Fourteenth Amendment and followed this suggestion with the claim that it may be possible to use education tests to keep out "people of alien races". Cockburn was concerned that by referring to the "subjects of the Queen" it would be difficult to legislate on racial grounds: "We desire always to deal with Asiatics on broad lines, whether they are subjects of the Queen or not; and in South Australian, and I believe in other colonies, those lines of distinction are obliterated". Higgins wanted to "prohibit any discrimination based upon a false principle," but did not reject the Western Australian legislation because "[t]here is no discrimination there based on residence or citizenship; it is simply based upon colour and race". As he openly declared, "[w]e want a discrimination based on colour". There were, according to Trenwith, "races within the nation that remain distinct; that are by their existence and by their rapid increase inimicable to the well-being of the whole community. This has been made very manifest in America". He considered the granting of citizenship to the "Negroes" a generous but unwise act. See in general Convention Debates, Melbourne, 1898, 1780-1802.

107 Per Isaacs, Kingston and Reid: ibid at 1798-1799.

108 To see the Constitution as a social contract was to misconceive the nature of society and therefore the best means for securing freedom and progress. Society was not an artificial entity that was constituted by agreement or contract (however fundamental), and therefore entrenching rights in a Constitution did not guarantee them. 
109 To the extent that progress also contemplated growth these views were not inconsistent. However, the inconsistencies between these views were evident when we recall Bentham's critique of the common law and the so-called natural basis of the society and laws.

110 See generally, the references above n 1; G Craven, above n 5; G Craven, "Original Intent and the Australian Constitution - Coming Soon to a Court Near You?" [1990] Public Law Review 166; Sir Daryl Dawson, "Intention and the Constitution - Whose Intent?" (1990) 6 Aust Bar Rev 93.

111 Especially since, as G Craven notes, above n 5 at 23, most approaches to the Constitution are to some extent intention based: "intentionalism directly; literalism intrinsically, in the sense that its conceptual validity depends upon its utility as a means of divining intention; and even progressivism, at least to the vestigial extent that it seems to posit the existence of some basic historical intent that the court should constantly revise the Constitution".

112 Of course this raises difficult questions as to when a certain practice can be said to be no longer contested as "civilised" and so on.

113 "Progressivism" is an approach to constitutional interpretation that maintains provisions should be given a meaning that is most consonant with contemporary society. See Craven, above $\mathrm{n} 5$ at 16 . Arguably there is a difference between applying the terms of the Constitution to changing circumstances and changing the meaning of its terms to accommodate modern developments. In this context note that the "living tree" metaphor, initially formulated by Lord Sankey in Edwards $v$ Attorney-General of Canada [1930] AC 124 at 136, assumed some plan or structure, that is, an original intent: a "living tree capable of growth and expansion within its natural limits" (emphasis added).

114 See J Goldsworthy, "The High Court, Implied Rights and Constitutional Change" (1995) Quadrant 46. The progressivist argument put forward by Deane $\mathrm{J}$ in Theophanous $v$ Herald and Weekly Times Ltd (1994) 182 CLR 104 at 171, assumes that by not amending the Constitution the people consent to its terms. However, leaving aside the difficulties associated with this consent argument (both practical and theoretical), as the quote from Inglis Clark in the judgment of Deane J indicates, this adoption argument presupposes "the language of their predecessors" and hence reintroduces the problem of originalism.

115 See the judgement of Deane J in Theophanous $v$ Herald and Weekly Times Ltd (1994) 182 CLR 104 at 163-188.

116 And therefore it is not necessary to defend judicial review as merely the protection of "neutral" democratic procedural rights; the Court protects substantive and procedural rights as the fruits of progress. See in this context J Waldron, "A Right-Based Critique of Constitutional Rights" (1993) 13 Oxford J Legal Studies 18; J Ely, Democracy and Distrust (1980).

117 For example, the rejection of "civilisation" as a standard by Brennan J in Mabo v Queensland (No 2) 


\section{(1992) 175 CLR 1.}

118 In which case the attempts to amend this liberalism by means of a judicial bill of rights derived from natural rights or human rights would appear contrary to the founders' intent. This raises questions regarding the support of Kirby J for the "Bangalore Principle": see M Kirby, "The Role of International Standards in Australian Courts" in P Alston and M Chiam (eds), Treaty-Making and Australia: Globalisation versus Sovereignty? (1995) 81. 